\title{
Effectiveness of Learning Model Concept Sentence With Media Puzzle of Activities and Description of Learning Outcomes Writing Skills Class III SD District of Kudus
}

\author{
Izzatul Munawaroh \\ \{izzatulmuna218@gmail.com\} \\ Faculty of Teaching and Education, Universitas Muria Kudus Gondang Manis PO BOX. 53 Bae \\ Kudus, Central Java Indonesia Phone (+62291) 438229, Fax (+62291) 437198
}

\begin{abstract}
This study aimed to analyze the effectiveness of the application of learning models Puzzle Concept Sentence media on the activities and results of the third grade students in learning Indonesian Writing materials Description. The research is a quasiexperimental study with a control group design nonequalivalent form. The population of this research was grade III primary school curriculum of 2013 more than 2 years in Kudus regency 2019/2020 school year as many as 11 elementary schools in the District Dawe.Selection of sampling in this research istechniques purposive sampling, Data collection through testing. The method uses the data analasisgains scores and ttest.Results of the analysis showed that n-gain media Puzzle Concept Sentence with the experimental class showed 0.63 and $\mathrm{N}$-gain the control class 0,52 so that both are included in the medium category. The results showed that the effectiveness of the model with the media Puzzle Concept Sentence t-test is based is known that tcount7.405greater than the value ttabel 2.0030. Conclusions This study is the Concept Learning model Sentence with Puzzle media more effectively used in the activities and learning outcomes Indonesian Writing materials Description of third grade students of elementary Holy District of the conventional learning models.
\end{abstract}

Keywords: Concept Sentence, Puzzle, Indonesian

\section{Introduction}

Education is an effort to develop students' abilities optimally through the influence of the environment with the aim of changing the behavior of students in order to be in harmony with the values developed in the community. Hamalik (2010:3) discloses a process of education is to influence students to be able to adapt as best as possible with the environment and cause a change in him so strongly to function in society.Effective learning is a measure of the success of teachers in classroom management. Learning is said to be effective if the learning outcomes and learning activities of students who use the learning approach is better than the conventional learning is still a certain level of completeness (Susanto, 2015: 54).

Based on the National Education Minister Regulation No. 22 of 2006 states that the language has a central role in the development of intelektuaal, social, and emotional learners and is supporting the success of learning across all subject areas. Learning the language is expected to help students know themselves, their culture, and the culture of others. Learning Indonesian directed to improve the ability of learners to communicate everyday written and 
spoken in the Indonesian language properly. Indonesian Education is expected to help students in expressing ideas and opinions, find and use analytical skills, communicate effectively in accordance with good ethics and correct.

Language skills are divided into four skills of listening, reading skills, speaking skills and writing skills. Tarigan (2008: 4) describes listening skills is a process which listened to the sounds of language, identify, interpret, assess, and react on the meaning contained in it. Tarigan (2008: 9) states that the skill of reading is to understand the language patterns of picture writing. Tarigan (2008: 16) the speaking skills is the ability to pronounce sounds articulation or words to express, express or convey thoughts, ideas, and feelings. Tarigan (2008: 3) describes the skill of writing is a language skill that is used to communicate indirectly, not face to face with another person.

Fourth language skills are very important in everyday life, particularly writing skills. Writing skills is one very important language skill to master because it requires someone to be able to use the language in writing properly. A person can express his ideas through writing without having to meet in person. However, most people do not realize the importance of writing skills, feeling lazy and reluctant to think and express his ideas through writing. Writing is a productive activity and eskpresif, so the writing should go through training and practice are numerous and regular. Through writing exercises regularly, can train the skills of a person to express his ideas through writing.

Based on observations, it is known that the ability of third-grade students in writing a description of the still low. In addition, the students' interest towards learning to write descriptions have not seen, because it is not accustomed to expressing ideas through writing. The problem is also supported by the value of Indonesian students learning outcomes based on the value of Deuteronomy Final II 2018/2019 academic year. Some students have not been getting grades that meet minimum completeness criteria (KKM). Of the 20 third-grade students, there are 11 students who earn grades completed by KKM 70. Students who pass are: 12 out of 20 students $(55 \%)$. Low student learning outcomes showed that most students understanding of the material to write the description on the Indonesian pembelejaran not meet the standards that have been set.

The problems that affect learning skills to write descriptions in need find a way out. To that end, the need for new models of learning, to improve the ability to write the essay description. Through models and instructional media, combined with the good, can be easier for students to express their ideas in writing and attract students to participate in the learning process. One model used is a model Concept Sentence. Huda (2013: 315) reveals that the sentence concept learning model is a model of learning that begins with the delivery of competency, grain material, the formation of a heterogeneous group, the keywords corresponding presentation materials, group assignments and presentation of results of learning and inference material.

In addition to learning models that have not implemented the teachers, the limitations of the media also affects textual and limitations of learning media to be one cause poor performance of students learning Indonesian. The media is one of communication, namely as a messenger from the communicator to the communicant. Learning media is a tool / vehicle used educators in the learning process to assist the delivery of learning message (Rifa'i 2012: 161). One medium that can be used for learning Indonesian is material to write descriptions of media puzzle.

Ismail (2012: 199) states that the puzzle is a game that make up an image or object that has been broken down into several parts. Use of the puzzle in the learning objectives are to 
improve the cognitive, affective, and psychomotor. Puzzle is expected to be an intermediary in the child's ability to optimize the three aspects.

\section{Research Methods}

The population in this study is the third grade students of elementary school that has implemented the curriculum in 2013 more than 2 years in the District Dawe Kudus district consisting of $11 \mathrm{SD}$. Sampling using purposive sampling techniques which have $2 \mathrm{SD}$ in accordance with the judgment. So that the selected SD 5 Cendono the control class and SD 1 Cendono the experimental class.

The method used to obtain research data is to use the test. The test method in the form of a pretest-posttest used to obtain data on student learning outcomes Indonesian. The learning model used in each of the same class, but the difference is the medium used, the experimental class using a model puzzle Concept Sentence with media control class while applying the learning model Sentence Concept models without media.

Test analysis conducted the analysis instrument and data analysis. The analysis includes the instrument validity test. The data analysis method consists of testing requirements analysis and final data analysis. Test requirements analysis includes median equality test, normality test, homogeneity and N-Gain test while final data analysis is by t test.

\section{Result dan Discussion}

Data Indonesian student learning outcomes obtained from the pretest and posttest. Pretest and posttest scores of students experimental class and control class is shown in Table 1 below.

Table 1. pretest and posttest scores Indonesian Learning Outcomes Student Class and Class

\begin{tabular}{lllllllll}
\multicolumn{10}{c}{ Experiment Control } \\
\hline \multirow{2}{*}{ Data } & $\mathrm{K}$ & $\mathrm{N}$ & $\begin{array}{l}\text { Ideal } \\
\text { score }\end{array}$ & $\begin{array}{l}\text { score } \\
\text { Min }\end{array}$ & $\begin{array}{l}\text { Max } \\
\text { score }\end{array}$ & Average & P (\%) & Ket \\
\hline \multirow{2}{*}{ pretest } & $\mathrm{ES}$ & 20 & 100 & 50 & 85 & 67.75 & 68 & $\mathrm{C}$ \\
& $\mathrm{K}$ & 20 & 100 & 40 & 80 & 65.33 & 65 & $\mathrm{C}$ \\
posttest & $\mathrm{E}$ & 20 & 100 & 85 & 100 & 88.33 & 88 & $\mathrm{~A}$ \\
& $\mathrm{~K}$ & 20 & 100 & 65 & 100 & 83.50 & 83 & $\mathrm{~B}$ \\
\hline
\end{tabular}

Table 1 it can be seen that the average value of learning outcomes Indonesian pretest experimental class 67.75 while the control class 65.33 both of which are included in the category. Scores increased after learning, the average score achieved by students experimental class88.33 while the control class 83.50. Experimental class that gets the higher score is the class that uses a learning model Sentence with media puzzle Concept.

Before learning to do, learning outcomes Indonesian students from two classes studied in the categoryC (medium). After learning Indonesian level learning outcomes of students in the experimental class reached category A (high) and the control class category B (high).

Test 2 the average statistical difference conducted to know the difference between pretest and posttest scores 2 class studied. At posttest have done tests of normality and homogeneity tests all normal distribution. Furthermore, to know the difference between pretest and posttest value then continued test of $\mathrm{N}$-Gain. 
Test gain score performed to determine the difference between the pretest and posttest. Gain test performed after all the test prerequisites are met, both the average similarity test, test for normality and homogeneity. Based on tests of normality and homogeneity note that the data were normally distributed and homogeneous, then the next test N-Gain. N-Gain test results can be seen in Table 2 below.

Table 2 N-Gain Calculation Results

\begin{tabular}{llll}
\hline \multirow{2}{*}{ Group } & \multicolumn{2}{l}{ Average } & N-Gain \\
\cline { 2 - 3 } & Initial tests & Final test & \\
\hline classroom Control & 65.33 & 83.50 & 0.52 \\
\hline experimental class & 67.75 & 88.33 & 0.63 \\
\hline
\end{tabular}

Table 2 it can be seen that the results of the N-gain the experimental class showed 0.63 and $\mathrm{N}$-gain the control class showed 0.52 . $\mathrm{N}$-Gain classification is as follows: $\mathrm{g}<0,30=\mathrm{low}, 030$ $<\mathrm{g}>0,70=$ medium, g $>0.70=$ high. Results $\mathrm{N}$-gain experimental class showed 0.63 and $\mathrm{N}-$ gain the control class 0,52 so that both are included in the medium category. The gain test results we can conclude that the difference between the experimental class is higher than the control class, it can be concluded that learning the experimental class is better than the control class. Furthermore, to prove the hypothesis then followed by t-test.

In a hypothesis test, there are some provisions that should be used as guidelines. The provision is that if $\mathrm{t}<\mathrm{t}$ table or significance value $>0.05$, h0 is received, and if $\mathrm{t}>\mathrm{t}$ table or significance value $<0.0$, then $\mathrm{h} 0$ rejected. In this study, researchers used a sample of 55 people, then the value of degrees of freedom (df) $=\mathrm{n}-2=55-2=53$ and standard error of $5 \%$ for the second test it can be seen the value $=2.042$ (Priyatno, 2010: 113), The result of the calculation hypothesis test using SPSS version 23 independent sample t test results are shown in Table 3.

Table 3. The results of the t-test analysis of the effectiveness of the learning model Sentence with media puzzle Concept on learning outcomes Indonesian students of class III SD

t-test for Equality of Means

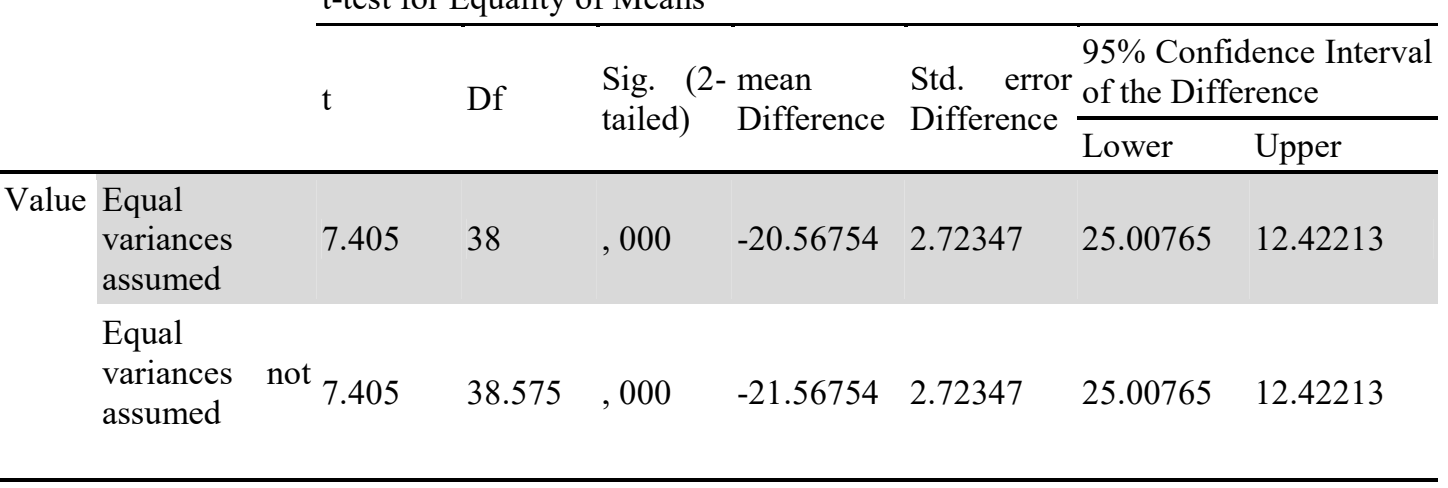

In Table 3 it can be seen that the calculation results of hypothesis test by using SPSS version 23 independent sample $\mathrm{t}$ test results showed equal variances assumed column on column t indicates 7.405; df is 38; sig. (2 tailed) 0.000 ; mean difference of 20.56754; lower at 
25.00765; Upper amounted to 12.42213. The next column equal variances not assumed in the column $\mathrm{t}$ indicates 7.405 ; df amounted to 38.575 ; sig. (2 tailed) 0.000 ; mean difference of 21.56754; lower amounting to 25.007645; Upper amounted to 12.42213 .

Note that the data in the study is homogeneous, then to find out the results of hypothesis testing can be seen in the column assumed equal variances. Conversely, if not homogeneous, to find out the results of hypothesis testing can be seen in the column equal variances not assumed. Based on the results of a calculation with SPSS version 23 column assumed equal variances can be seen that the value of $t=7.405$ and significance of 0.000 . From the results of these calculations can be seen that $7.405>2.0030$ or $t>t$ table and $0.000<0.025$ or significance value $<0.025$. Based on t-test that has researchers have described above, then $\mathrm{H} 0$ is rejected and Ha accepted. Thus, the conclusions of this study are learning Sentence Concept model of the experimental class against Indonesian student learning outcomes more effectively,

Implementation of effective learning model Concept Sentence for by Huda (2014: 317) has the following advantages:

a. Improving student learning spirit.

b. Help create a conducive learning atmosphere.

c. Bring up the excitement in learning.

d. Encourage and develop creative thinking processes.

e. Encourage students to look at things in a different view.

f. Raising awareness to change for the better.

g. Strengthen self-awareness.

h. Better understand the key words of the subject matter.

i. Students who are smarter teach students who are less intelligent.

Concept Sentence learning model and lectures with discussion and question and answer variations together requires that students learn in groups. This is done so that students can exchange information and opinions to complete the task. Differences were seen in both classes are on a cooperative learning model Concept Sentence students practice stringing sentences of keywords submitted by teachers so that students learn more pleasant atmosphere and all students can participate actively in learning.

Benefits puzzle according Soedjatmiko (2009) are as follows.

a. improve cognitive ability, the ability to know and remember,

b. improve motor skills, the ability to coordinate limbs such as hands and feet,

c. improve the ability of logic, the ability to think properly and regularly,

d. improve the ability of creative / imaginative, the ability to generate ideas within the context,

e. improve visual ability, the ability of the eye catching shapes and colors of objects.

Average increase student learning outcomes were also obtained from the gain test the experimental class in middle category is 0.63 while the control class are also on the criteria being that is 0.52 . This shows that the use of cooperative learning model Sentence with media puzzle Concept effectively improve student learning Indonesian writing description materials class III.

This shows that the use of cooperative learning model Sentence with media puzzle Concept effectively improve learning outcomes Indonesian students writing description of the class III material.

This is supported by the results of research conducted by Purnama Sari Asih (2014) which shows the difference in student learning outcomes significantly between learning the concept model of sentence and which are not. The results of student learning outcomes U test showed 
$0.000<0.05$. The results showed an increase in student learning outcomes. The average percentage of student learning outcomes in experimental class is 88.28 , while the control class is 80.71 .

Another study was also carried out by Nida Qurrati Ain (2018) shows the results obtained by $\mathrm{t}$ test $\mathrm{t}=13.618$ price while the price table $=2.056$. Because $\mathrm{t}>\mathrm{t}$ table ie 13.618>2.056, the null hypothesis is rejected.

Research conducted by Natalia Wit, et al (2017) with the results of hypothesis testing on the data obtained posttest note that the value was 19.84 whereas Zhitung Ztabel value at $\alpha=$ $5 \%$ was 1.96 . This means that the value Zhitung $>$ Ztabel (19.84> 1.96) then H1 accepted.

Based on the description, the use of models Concept Sentence with media puzzle learning to write descriptions Indonesian material is effectively used when learning activities that can be used as an alternative in learning Indonesian material to write descriptions in class III.

\section{Conclusion}

Concept Sentence learning model with puzzles media more effectively use the learning outcomes Indonesian Writing materials Description of third grade students of elementary Holy District of the conventional learning models. Models Concept Sentence effectiveness with media based puzzle t-test is known that tcount7.405greater than the value tabel 2.0030 .

Teachers in selecting instructional media models and should be tailored to the characteristics and abilities. So that when the learning material presented will be easier to understand and create a fun learning environment.

\section{References}

[1] Badan Penelitian dan Pengembangan. Standar Kompetensi Bahasa Indonesia. Jakarta: Departemen Pendidikan Nasional. Tersedia di http:// rumahinspirasi.com/wpcontent/uploads/2009/08/Bahasa Indonesia.pdf. (2003)

[2] Hamalik, Oemar. Kurikulum dan Pembelajaran. Jakarta: Bumi Aksara. (2015)

[3] Huda, Miftahul. Model-Model Pengajaran dan Pembelajaran. Yogyakarta: Pustaka Belajar. (2013)

[4] Ismail, Andang. Education Games. Yogyakarta: Pro-U Media. (2012)

[5] Qurrati, Nida. Pengaruh Model Concept Sentence Terhadap Keterampilan Menulis Karangan Sederhana Pada Siswa Kelas IV SDN Kerangkulon 1 Demak. Jurnal Sekolah (JS). p-ISSN: 2548 - 8856 e-ISSN: 2549 - 127X. Vol 2 (2). (2018)

[6] Rifa'i, Achmad dan Catharina Tri A. Psikologi pendidikan. Semarang: Unnes Press. (2012)

[7] Sari, Asih Purnama. Keefektifan Model Concept Sentence Terhadap Aktivitas dan Hasil Belajar Menulis Narasi. Journal of Elementary Education. ISSN 2252-9047. Vol 3 (1). (2014)

[8] Susanto, Akhmad. Teori Belajar \& Pembelajaran di Sekolah Dasar. Jakarta: Prenada Media. (2015)

[9] Tarigan, Henry Guntur. Menulis: Sebagai Suatu keterampilan Berbahasa. Bandung: Angkasa. (2008)

[10] Undang-Undang R.I Nomor: 20 Tahun 2003 Tentang Sistem Pendidikan Nasional. Jakarta: BP. Dharma Bhakti. (2003)

[11] Wit, Natalia. Efektivitas Model Pembelajaran Concept Sentence Terhadap Hasil Belajar Kognitif Siswa Pada Materi Alat Indra Manusia Kelas IX Sekolah Menengah 
Pertama Negeri 1 Kayan Hilir Tahun Pelajaran 2017/2018. JPBIO (Jurnal Pendidikan Biologi). Vol. 2 No. 1 April, ISSN 2540-802x. (2017) 